Web Jurnal:

http://ejournal.kemenperin.go.id/jli

\title{
Sintesis dan karakterisasi biosorben berbasis tannin gambir (Uncaria gambier Roxb.) dan aplikasinya pada penyerapan ion logam $\mathbf{P b}^{2+}$
}

\section{Synthesis and characterization of tannin based biosorbent from Uncaria gambier Roxb. and its aplication for adsorption of $\mathrm{Pb}^{2+}$}

\author{
Muhammad Fajri Nurmawan*, Citra Setiawati, dan Nur Aini Haryati \\ Balai Riset dan Standardisasi Industri Padang \\ Jalan Raya LIK No. 23, Kota Padang, Indonesia, Kode Pos 25164 \\ * e-mail: muhammadfajrinurmawan@gmail.com
}

\begin{tabular}{|c|c|}
\hline INFO ARTIKEL & ABSTRAK \\
\hline $\begin{array}{l}\text { Sejarah artikel: } \\
\text { Diterima : } \\
9 \text { Oktober } 2020 \\
\text { Direvisi : } \\
7 \text { Desember } 2020 \\
\text { Diterbitkan : } \\
28 \text { Desember } 2020\end{array}$ & $\begin{array}{l}\text { Ekstrak tanin gambir (Uncaria gambier Roxb.) memiliki potensi sebagai bahan baku } \\
\text { pembuatan biosorben yang dapat diaplikasikan untuk adsorpsi ion logam } \mathrm{Pb}^{2+} \text {. Gel tanin } \\
\text { gambir (Gambier Tannin Gel, GTG) telah disintesis melalui reaksi polimerisasi dengan } \\
\text { penambahan formaldehida dalam suasana basa } \mathrm{NaOH} \text { selama } 8 \text { jam pada suhu } 80^{\circ} \mathrm{C} \text {. } \\
\text { Karakterisasi spektrum inframerah dengan FT-IR Spectrophotometer menunjukkan } \\
\text { adanya jembatan metilen ( }-\mathrm{CH}_{2}-\text { ) dan jembatan metilen eter }(\mathrm{C}-\mathrm{O}-\mathrm{C}) \text { ditandai dengan } \\
\text { pita serapan pada bilangan gelombang masing-masing } 2910 \mathrm{~cm}^{-1} \text { dan } 1040 \mathrm{~cm}^{-1} \text {. Hasil } \\
\text { pembacaan pola difraksi sinar X dengan X-Ray Diffractometer (XRD) menunjukkan }\end{array}$ \\
\hline $\begin{array}{l}\text { Kata kunci: } \\
\text { tannin; } \\
\text { biosorben; } \\
\text { Uncaria gambier } \\
\text { Roxb.; } \\
\text { timbal; } \\
\text { kapasitas adsorpsi }\end{array}$ & $\begin{array}{l}\text { bahwa GTG yang dihasilkan memiliki tingkat kristalinitas yang rendah dengan ukuran } \\
\text { kristal sebesar } 1,07-2,82 \AA \text {. Penentuan kapasitas adsorpsi menggunakan pola isoterm } \\
\text { Freundlich dan Langmuir dengan variasi konsentrasi } \mathrm{Pb}^{2+} \text { sebesar } 5,10,15,20,25 \text {, dan } \\
30 \text { ppm. Banyaknya ion logam yang terserap diukur dengan Atomic Absorption } \\
\text { Spectrophotometer (AAS). Dari hasil penelitian, diketahui bahwa proses adsorpsi ion } \\
\text { logam } \mathrm{Pb}^{2+} \text { oleh GTG mengikuti persamaan isoterm adsorpsi Freundlich dengan } \\
\text { kapasitas adsorpsi maksimum sebesar } 0,4917 \mathrm{mg} / \mathrm{g} \text {. }\end{array}$ \\
\hline
\end{tabular}

\section{Keywords:}

tannin;

biosorbent;

Uncaria gambier

Roxb.;

lead;

adsorption capacity

\begin{abstract}
Uncaria gambier Roxb tannin extract has a potential as a raw material for biosorbents which can be applied for adsorption of $\mathrm{Pb}^{2+}$. Gambier tannin gel (GTG) has been synthesized through a polymerization reaction with the addition of formaldehyde in an alkaline at atmosphere of $\mathrm{NaOH}$ for 8 hours at $80{ }^{\circ} \mathrm{C}$. Characterization of the infrared spectrum by FT-IR Spectrophotometer showed the presence of methylene bridges $\left(-\mathrm{CH}_{2}-\right)$ and a methylene ether bridges $(\mathrm{C}-\mathrm{O}-\mathrm{C})$ characterized by absorption bands at wave numbers of $2910 \mathrm{~cm}^{-1}$ and $1040 \mathrm{~cm}^{-1}$, respectively. The result of $X$-ray diffraction pattern reading with $X$-Ray Diffractometer (XRD) showed that the resulting GTG has a low crystallinity level with a crystal size range of 1.07-2.82 A. Determination of the adsorption capacity using Freundlich and Langmuir isotherm patterns with variations in the concentration of $\mathrm{Pb}^{2+}$ of 5, 10, 15, 20, 25, and $30 \mathrm{ppm}$. The amount of metal ions absorbed was measured by an Atomic Absorption Spectrophotometer (AAS). From the results, it is known that the adsorption process of $\mathrm{Pb}^{2+}$ by GTG follows the Freundlich adsorption isotherm equation with a maximum adsorption capacity of $0.4917 \mathrm{mg} / \mathrm{g}$.
\end{abstract}

\section{Pendahuluan}

Tanaman gambir (Uncaria gambir Roxb.) merupakan salah satu komoditas tanaman industri yang memiliki nilai ekonomi tinggi serta prospektif untuk dikembangkan oleh petani maupun dikelola secara komersial menjadi produk-produk olahan gambir yang memiliki nilai jual yang lebih tinggi (Yeni et al., 2017). 
Tanaman gambir merupakan tanaman belukar dari famili Rubiaceae yang tumbuh pada ketinggian antara 0-800 $\mathrm{m}$ dari permukaan laut. Tanaman ini terdiri atas 34 genera, satu genus terdapat di Afrika, dua genus di Amerika, dan selebihnya terdapat di Asia, khususnya Indonesia. Sentra perkebunan tanaman gambir di Indonesia berada di wilayah Sumatera, Bangka Belitung, dan Papua (Yeni et al., 2014).

Gambir merupakan sari getah yang diekstraksi dari daun maupun ranting tanaman gambir yang diperoleh dengan berbagai cara pengolahan, baik pengolahan tradisional maupun pengolahan modern dengan peralatan-peralatan mekanis. Ekstrak tanaman gambir tersebut tersedia dalam berbagai bentuk dan dikeringkan (Fauza, 2014). Kandungan senyawa kimia yang aktif dalam gambir sangat dipengaruhi oleh sumber tanaman gambir tersebut berasal. Selain itu kandungan senyawa aktif dalam gambir juga dipengaruhi oleh setiap perlakuan dan proses ekstraksi yang berbeda. Secara umum kandungan komponen aktif dalam gambir terdiri dari katekin (7-33\%), asam kateku tanat (20-55\%), dan pyrokatekol (20-30\%) (Ferdinal, 2014). Senyawa tanin memiliki cukup banyak gugus hidroksil untuk berikatan silang (cross-linking)secara efektif dengan senyawa lain (Hafiz et al., 2020).

Data dari BPS menunjukkan produksi gambir Sumatera Barat dari tahun ke tahun terus menurun. Pada tahun 2015 tercatat produksi gambir Sumatera Barat yaitu 17.390,8 Ton, sedangkan pada Tahun 2019 produksi gambir Sumatera Barat turun hingga 7.582,0 Ton. Bila dibandingkan dengan total lahan tanaman gambir yang ada tidak terdapat banyak perubahan yaitu 32.308,80 Ha pada tahun 2015 menjadi 28.739,50 Ha (Badan Pusat Statistik Sumatera Barat, 2020). Hal ini menunjukkan bahwa banyak lahan gambir yang sudah tidak dimanfaatkan oleh petani dikarenakan harga gambir yang relatif rendah setiap tahunnya. Oleh karena itu, perlu adanya diversifikasi dari tanaman gambir menjadi produk turunan yang lebih bernilai jual.

Ekstrak gambir berupa tanin telah dimanfaatkan sebelumnya dalam berbagai aplikasi seperti sediaan bahan baku farmasi (Anggraini et al., 2013), pewarna alam (Failisnur and Sofyan, 2016) dan bahan penyamak kulit (Yeni et al., 2016). Pemanfaatan senyawa tanin sebagai biosorben sudah dilakukan sebelumnya, namun senyawa tanin yang digunakan pada umumnya bersumber dari kulit pohon mimosa, kayu quebracho, kayu pinus dan lain-lain (Arbenz and Avérous, 2015); (Beltrán-Heredia et al., 2012); (Sánchez-Martín et al., 2011, 2010) Penggunaan biomassa sebagai sumber bahan baku pembuatan adsorben (biosorben) semakin meningkat dalam beberapa tahun terakhir. Hal ini disebakan karena biomassa merupakan bahan baku yang dapat diperbarui, relatif murah, proses sintesis yang sederhana serta dapat diaplikasikan dalam penanganan limbah cair (Bacelo et al., 2016). Studi tentang pemanfaatan senyawa tanin dari ekstrak gambir untuk biosorben merupakan topik yang menarik untuk dikaji secara lebih lanjut. Pemilihan gambir sebagai bahan baku biosorben didukung dengan ketersediaannya yang cukup melimpah dan dapat dibudidayakan, serta memiliki kandungan senyawa tanin yang tinggi. Senyawa tanin memiliki banyak gugus hidroksil pada struktunya sehingga berpotensi digunakan sebagai adsorben kationik.

Tanin merupakan senyawa yang larut dalam air sehingga sebelum digunakan sebagai biosorben dibutuhkan proses tertentu agar senyawa tanin menjadi senyawa yang tidak larut (insolubilisasi/imobilisasi) (Bacelo et al., 2016). Proses insolubilisasi telah dilakukan pada beberapa penelitian sebelumnya dalam kondisi dan metode yang berbeda. Perbedaan kondisi dalam pembuatan biosorben berbasis tanin menghasilkan produk biosorben yang berbeda-beda seperti: gel tanin (Sánchez-Martín et al., 2010), gel tanin yang dimodifikasi (Morisada et al., 2011), gel tanin yang diimobilisasi (Xu et al., 2017) dan busa tanin (Santiago-Medina et al., 2018).

Pembuatan biosorben berbasis tanin dalam bentuk gel telah dilakukan dengan menggunakan bahan alam seperti kulit batang mimosa (Acacia mearnsii atau mollissima) dan kulit batang cypress (Cupressus sempervirens) (Beltrán-Heredia et al., 2012), persimmon (Gurung et al., 2011), kulit batang pinus (Pinus radiata) dan kayu quebracho (Schinopsis balansae) (SánchezMartín et al., 2010). Namun demikian, pembuatan gel tanin dari gambir sebagai biosorben belum banyak dilaporkan.

Beberapa penelitian melaporkan kemampuan biosorben berbasis tanin dalam mengadsorpsi logam berat dalam larutan berair seperti timbal (Wang et al., 2013), kromium (Alvares Rodrigues et al., 2015), nikel (Meethale Kunnambath and Thirumalaisamy, 2015), antimon (Bacelo et al., 2018) dan tembaga (Sun et al., 2020; Xu et al., 2017). Hal ini dikarenakan sifat kationik dari logam-logam tersebut di dalam larutan cocok dijadikan sebagai target dalam penggunaan biosorben berbasis tanin.

Ion logam timbal $\left(\mathrm{Pb}^{2+}\right)$ merupakan salah satu pencemar yang bersifat sangat toksik dan berbahaya bagi lingkungan. Cemaran $\mathrm{Pb}^{2+}$ dapat berasal dari limbah industri baterai, pulp dan kertas, reaktor nuklir, pertambangan, peleburan timbal, pewarnaan, dan industri otomotif. Kontaminasi ion logam $\mathrm{Pb}^{2+}$ dalam tubuh manusia dapat menyebabkan kerusakan sel darah merah, penurunan hemoglobin, kerusakan hati dan ginjal, serta gangguan mental dan penurunan IQ (Yurtsever and Şengil, 2009); (Deviyanti et al., 2014).

Ion logam $\mathrm{Pb}^{2+}$ tidak dapat terurai oleh proses alam sehingga perlu dicegah untuk masuk ke perairan. Salah 
satu caranya adalah dengan penyerapan ion logam $\mathrm{Pb}^{2+}$ dalam limbah menggunakan biosorben. Berdasarkan hal tersebut, dilakukan penelitian tentang sintesis dan karakterisasi biosorben berbasis tanin dari ekstrak gambir (Uncaria gambier Roxb.) dalam bentuk gel tanin gambir (gambier tannin gel, GTG) yang diaplikasikan untuk adsorpsi ion logam $\mathrm{Pb}^{2+}$.

\section{Metode}

Bahan yang digunakan adalah serbuk tanin gambir/tannin powder (produksi CV Kempan di Kabupaten Lima Puluh Kota, Sumatera Barat), formaldehida p.a (Merck), $\mathrm{NaOH} \mathrm{0,125} \mathrm{mol} \mathrm{L}-1, \mathrm{HNO}_{3}$ 0,01 mol L-1, larutan $\mathrm{Pb}\left(\mathrm{NO}_{3}\right)_{2}, \mathrm{HNO}_{3}$ pekat dan aquadest. Peralatan yang digunakan adalah labu didih, kondensor, termometer, hot plate magnetic stirrer, neraca analitik, oven, shaker, pipet, spatula, dan peralatan gelas.

\subsection{Sintesis biosorben berbasis tanin gambir}

Sintesis biosorben dari tanin dilakukan sesuai prosedur yang dilaporkan oleh (Sánchez-Martín et al., 2011). Sebanyak $5 \mathrm{~g}$ tannin powder dilarutkan dalam 32 $\mathrm{mL} \mathrm{NaOH} 0,125 \mathrm{~mol} \mathrm{~L}^{-1}$ dan $30 \mathrm{~mL}$ aquadest pada suhu $80{ }^{\circ} \mathrm{C}$. Setelah larutan homogen, kemudian ditambahkan 3,68 $\mathrm{mL}$ formaldehida (p.a.). Pengadukan terus dilakukan pada suhu $80{ }^{\circ} \mathrm{C}$ selama 8 jam hingga reaksi polimerisasi dianggap telah selesai. Gel tanin yang diperoleh dimasukkan ke dalam oven pada suhu $65^{\circ} \mathrm{C}$ hingga kering kemudian digerus hingga menjadi serbuk. Selanjutnya, serbuk dicuci dengan $\mathrm{HNO}_{3} \quad 0,01$ mol L-1 untuk menghilangkan sisa $\mathrm{NaOH}$ dan dicuci dengan aquadest, lalu dikeringkan kembali di dalam oven pada suhu $65{ }^{\circ} \mathrm{C}$ sehingga diperoleh gel tanin gambir (Gambier Tannin Gel, GTG).

\subsection{Karakterisasi biosorben berbasis tanin gambir}

Spektrum inframerah dari ekstrak tanin gambir dan GTG diukur dengan alat Fourier Transform-Infra Red/FT-IR Spectrophotomer (PerkinElmer Frontier Optica) di Laboratorium Fisika Universitas Negeri Padang. Sedangkan pola difraksi tanin gambir dan GTG diamati dengan alat X-Ray Diffractometer/XRD (Philips/ PANalytical X'Pert Pro Multipurpose Powder Diffractometer) di Laboratorium Fisika Universitas Indonesia.

Ukuran kristal yang terbentuk dapat diketahui dengan menggunakan persamaan Scherrer sebagai berikut:

$$
\mathrm{D}=\frac{\mathrm{K} \lambda}{\beta \cos \theta}
$$

Dimana:

$\mathrm{D}=$ ukuran kristal

$\mathrm{K}=$ faktor bentuk dari kristal $(0,9-1)$

$\lambda=$ panjang gelombang dari sinar $X(1,54056)$

$\beta=$ nilai dari Full Width at Half Maximum (FWHM) (rad)

$\theta=$ sudut difraksi $\left(^{\circ}\right)($ Masruroh et al., 2013)

\subsection{Uji kapasitas adsorpsi ion logam $\mathbf{P b}^{2+}$}

Kapasitas adsorpsi adalah kemampuan suatu adsorban dalam menyerap atau mengadsropsi adsorbat. Penentuan kapasitas adsorpsi dilakukan untuk mengetahui kemampuan suatu adsorben dalam menyerap ion $\mathrm{Pb}^{2+}$ (Deviyanti, et al, 2014). Uji kapasitas adsorpsi ion logam $\mathrm{Pb}^{2+}$ dilakukan di Laboratorium Instrumentasi Baristand Industri Padang menurut prosedur (Deviyanti et al., 2014). Sejumlah biosorben $(0,5 \mathrm{~g})$ ditambahkan ke dalam gelas piala yang berisi larutan sampel yang mengandung ion logam $\mathrm{Pb}^{2+}$ dengan variasi konsentrasi $5,10,15,20,25$, dan 30 ppm. Larutan diaduk dengan shaker selama tiga jam kemudian disaring dengan kertas saring. Filtrat ditambahkan dengan larutan $\mathrm{HNO}_{3}$ pekat untuk mencegah pengendapan ion logam $\mathrm{Pb}^{2+}$. Adsorbansi ion logam $\mathrm{Pb}^{2+}$ yang tidak terserap oleh biosorben kemudian diukur dengan menggunakan Atomic Absorption Spectrophotometer/AAS (GBC 932 AA).

Penentuan kapasitas atau kemampuan serap dari biosorben berbasis tanin didasarkan pada persamaan garis lurus isoterm dengan melihat pola isoterm adsorpsi yang sesuai diantara isoterm Freundlich dan isoterm Langmuir. Isoterm adsorpsi Langmuir didasarkan pada asumsi bahwa adsorpsi tidak dapat berlangsung melebihi satu lapisan (Jasmal et al., 2015). Bentuk linear dari persamaan isoterm Langmuir ditunjukkan pada persamaan (2).

$$
\frac{\mathrm{C}}{\mathrm{q}}=\frac{1}{\mathrm{Q}_{0} \mathrm{~K}_{\mathrm{L}}}+\frac{\mathrm{C}_{\mathrm{e}}}{\mathrm{Q}_{0}}
$$

Isotermal Adsorpsi Freundlich digunakan pada energi permukaan yang heterogen dengan konsentrasi yang berbeda-beda. Isoterm Freundlich merupakan persamaan yang menghubungkan jumlah zat yang teradsorpsi dengan konsentrasi zat dalam larutan. Bentuk linear dari persamaan isoterm Freundlich ditunjukkan oleh persamaan (3) (Aisyahlika et al., 2018).

$$
\log \mathrm{q}=\log \mathrm{K}_{\mathrm{F}}+\frac{1}{\mathrm{n}} \log \mathrm{C}
$$

\section{Hasil dan pembahasan}

\subsection{Sintesis biosorben berbasis tannin gambir}

Pembuatan biosorben berbasis tanin dari gambir dilakukan melalui metode insolubilisasi dengan mereaksikan senyawa tanin dengan formaldehida atau senyawa aldehida lainnya. Reaksi polimerisasi terjadi secara bertahap dengan bantuan katalis asam atau basa. Pada penelitian ini digunakan pereaksi formaldehida dan $\mathrm{NaOH}$ sebagai katalis basa. Dalam reaksi tersebut, senyawa aldehid membentuk hubungan antara monomer tanin atau bertindak sebagai agen pengikat antar monomer tanin tersebut. Polimer tanin non-linear tak larut yang telah disintesis itulah yang dikenal sebagai gel tanin. 
(a)<smiles>[R]c1cc(C2Oc3cc(O)cc([R])c3CC2O)cc(O)c1O</smiles><smiles>[R]c1cc(C2Oc3c(c([R])cc(O)c3CO)CC2O)cc(O)c1O</smiles>

(b)<smiles>[Z10]c1cc(C2Oc3c(c([R8])cc(O)c3CO)CC2O)cc(O)c1O</smiles>

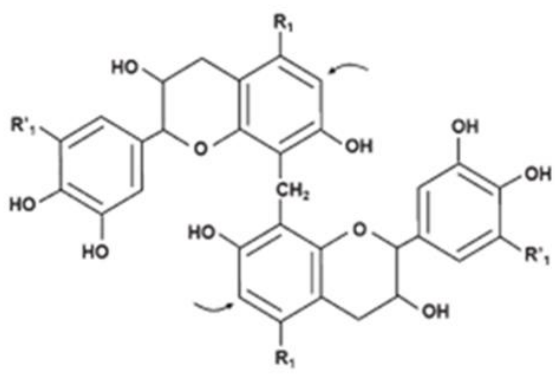

(c)

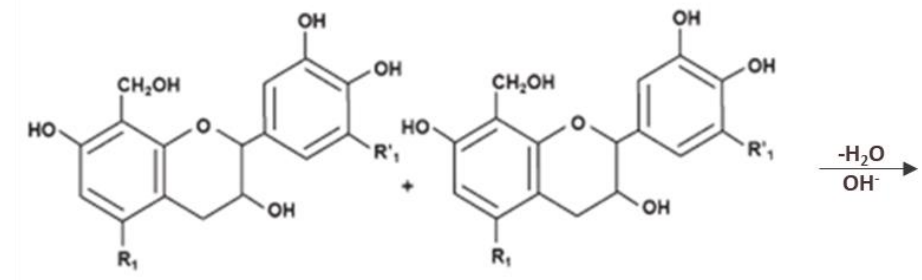<smiles>[R8]c1cc([C@@H]2C[C@@H](O)c3c([R8])c(CC)c(O)c(COCc4c(O)c(CC)c([R8])c5c4O[C@H](c4cc([Z7])c(O)c(O)c4)[C@@H](O)C5)c3O2)cc(O)c1O</smiles>

Gambar 1. Mekanisme reaksi polimerisasi senyawa tanin melalui tahap pertama (a) hydroxy methylation dengan penambahan formaldehid, serta tahap kedua (b) pembentukan jembatan metilen atau (c) pembentukan jembatan metilen eter (Beltran-Heredia et al., 2012)

Pada tahap pelarutan ekstrak tanin dalam larutan $\mathrm{NaOH}$, terjadi pengikatan proton pada gugus senyawa tanin yang meningkatkan kereaktifan senyawa tersebut. Penambahan formaldehida kemudian menyebabkan reaksi polimerisasi dengan cara pembentukan jembatan metilen dan metilen eter antar monomer tanin. Mekanisme reaksi polimerisasi tanin dari larutan ekstrak tanin ketika ditambahkan formaldehida telah digambarkan oleh Beltrán-Heredia et al. (2012) sebagaimana terlihat pada Gambar 1. Secara visual, biosorben yang diperoleh dari proses polimerisasi berupa serbuk yang berwarna cokelat.

\subsection{Karakterisasi biosorben berbasis tanin gambir}

Dari pengukuran dengan spektrofotometer FT-IR pada panjang gelombang 4000-500 $\mathrm{cm}^{-1}$ diperoleh spektrum inframerah ekstrak tanin gambir dan biosorben berbasis tanin gambir (Gambier Tanin Gel, GTG) seperti pada Gambar 2. Secara umum tidak ada perbedaan yang signifikan antara spektrum ekstrak tanin gambir dan GTG. Hal ini dikarenakan senyawa tanin hanya mengalami reaksi polimerisasi antara monomer satu dengan yang lainnya melalui pembentukan jembatan metilen dan jembatan metilen eter (Sánchez-Martín et al., 2010). Polimerisasi ini menghasilkan senyawa dengan ukuran molekul yang lebih besar namun struktur unit pembentuknya masih tetap. Namun demikian, dapat dilihat adanya puncak kecil pada bilangan gelombang 2950-2850 $\mathrm{cm}^{-1}$ menandakan keberadaan jembatan metilen $\left(-\mathrm{CH}_{2}-\right)$ yang berasal dari polimerisasi senyawa tanin (Sánchez-Martín et al., 2010).

Pada Gambar 2 terlihat pita serapan kuat pada bilangan gelombang $3600-3000 \mathrm{~cm}^{-1}$ yang menandakan keberadaan gugus hidroksil $(-\mathrm{OH})$ pada ekstrak gambir dan GTG (Sánchez-Martín et al., 2010). Jika dibandingkan dengan spektrum inframerah ekstrak tanin gambir, terdapat sedikit penurunan intensitas serapan yang menunjukkan berkurangnya jumlah gugus hidroksil akibat bereaksi dengan formaldehid dan selanjutnya membentuk jembatan metilen atau jembatan metilen eter.

Intesitas dari pita serapan gugus hidroksil yang besar menandakan bahwa senyawa tanin maupun polimernya mengandung gugus hidroksil dari fenol yang bebas (Silfia et al., 2018). Adanya gugus hidroksil dari fenol dalam ekstrak tanin dan GTG memberikan sifat anionik karena mampu melepaskan proton $\left(\mathrm{H}^{+}\right)$dan menciptakan muatan negatif yang distabilkan oleh resonansi. Adanya muatan negatif menjadikan senyawa ini cocok digunakan pada adsorpsi kation melalui interaksi elektrostatik dan mekanisme pertukaran ion (Bacelo et al., 2016). 


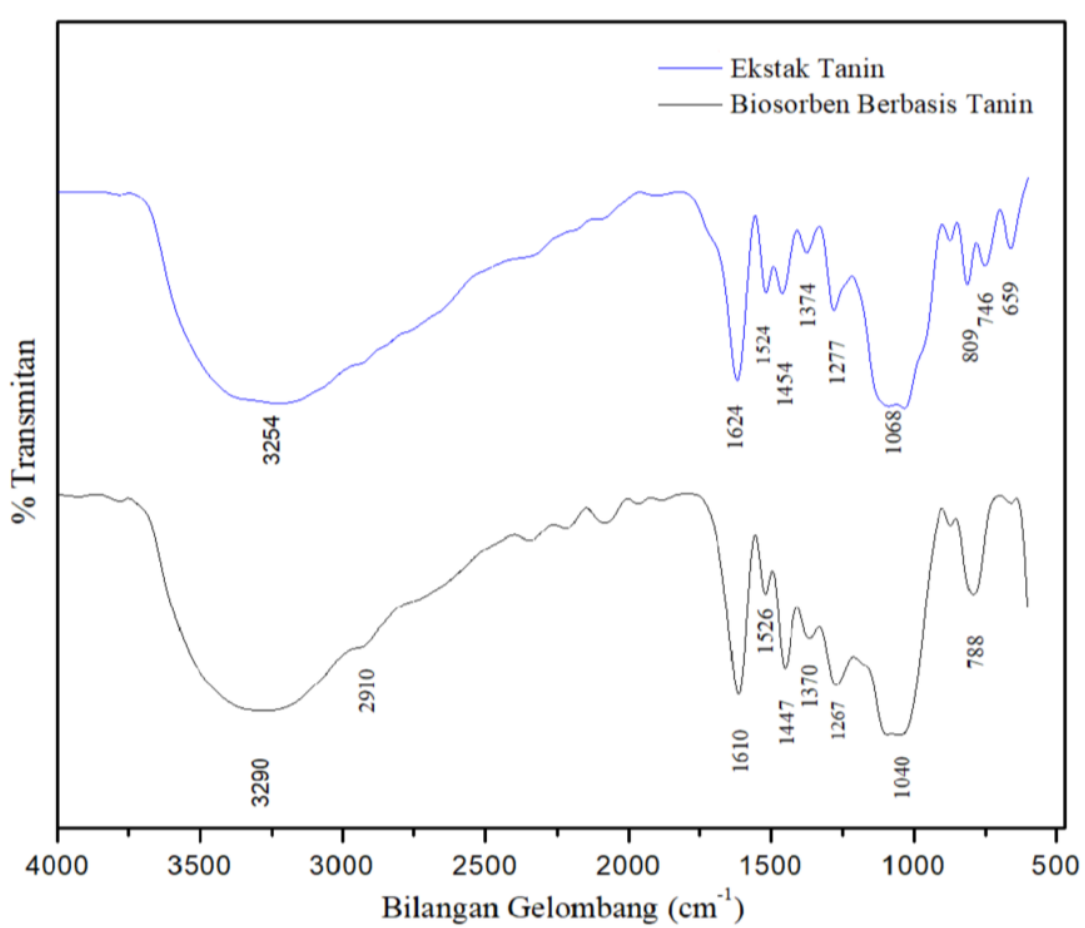

Gambar 2. Spektrum inframerah dari ekstrak tanin gambir dan biosorben berbasis tanin gambir (GTG)

Pita serapan pada bilangan gelombang $1610 \mathrm{~cm}^{-1}$ dan $1526 \mathrm{~cm}^{-1}$ merupakan karakteristik dari perpanjangan ikatan aromatik $-\mathrm{C}=\mathrm{C}-$, sedangkan serapan pada bilangan gelombang $1447 \mathrm{~cm}^{-1}$ diakibatkan oleh vibrasi deformasi ikatan $\mathrm{C}-\mathrm{C}$ dalam gugus fenolik. Selanjutnya, pita serapan yang tampak pada bilangan gelombang $1370 \mathrm{~cm}^{-1}$ dapat dikaitkan dengan vibrasi deformasi ikatan $\mathrm{O}-\mathrm{H}$ dari gugus fenolik atau alkohol. Pita serapan pada bilangan gelombang $1267 \mathrm{~cm}^{-1}$ dapat dikaitkan dengan peregangan - $\mathrm{CO}$ pada cincin aromatik dan jembatan metilen eter yang dibentuk oleh reaksi dengan formaldehida. Pita serapan pada bilangan gelombang $1040 \mathrm{~cm}^{-1}$ disebabkan oleh regangan $\mathrm{C}-\mathrm{O}-\mathrm{C}$ asimetris dari jembatan metilen eter dan deformasi $\mathrm{C}-\mathrm{H}$. Sementara itu, pita serapan pada bilangan gelombang $788 \mathrm{~cm}^{-1}$ dihasilkan oleh vibrasi deformasi ikatan $\mathrm{C}-\mathrm{H}$ dalam cincin aromatik (Sánchez-Martín et al., 2010).

Data spektrum inframerah yang diperoleh untuk GTG memiliki kesesuaian dengan spektrum gel tanin dari kulit batang quebracho (Quebracho Tannin Gel, QTG) yang disintesis dengan metode yang sama (Sánchez-Martín et al., 2010). Perbandingan spektrum inframerah antara GTG dan QTG disajikan pada Tabel 1.

Tabel 1.

Perbandingan spektrum inframerah antara GTG dan QTG

\begin{tabular}{lll}
\multicolumn{2}{l}{$\begin{array}{l}\text { Bilangan gelombang }\left(\mathrm{cm}^{-1}\right) \\
\text { GTG }\end{array}$} & $\begin{array}{l}\text { Ikatan yang } \\
\text { menyebabkan serapan }\end{array}$ \\
\hline 3290 & 3400 & O-H \\
2910 & 2900 & $-\mathrm{CH}_{2}-$ bridges \\
1610 & 1611 & $-\mathrm{C}=\mathrm{C}-$ aromatic \\
1526 & 1520 & $\mathrm{O}-\mathrm{H}$ bending \\
1370 & 1383 & $\mathrm{C}-\mathrm{O}$ \\
1267 & 1209 & $\mathrm{C}-\mathrm{O}-\mathrm{C}$ asymetric, $\mathrm{C}-\mathrm{H}$ \\
1040 & 1037 & $\mathrm{C}-\mathrm{H}$ aromatic \\
788 & 650 & \\
\hline
\end{tabular}

Reaksi polimerisasi oleh aldehid dapat menyebabkan perubahan dalam struktur molekul dan kristalinitas dari biosorben, sehingga pemahaman tentang struktur molekul dan kristal dari adsorben dan perubahan yang dihasilkannya dapat memberikan informasi mengenai pembuatan biosorben (Meethale Kunnambath and Thirumalaisamy, 2015). Hasil analisis XRD menunjukkan tingkat kristalinitas dari ekstrak tanin dan GTG. Pola difraksi yang diperoleh juga memberikan informasi mengenai ukuran kristal. Hasil analisis XRD untuk puncak-puncak tertinggi dari ekstrak tanin gambir dan GTG ditunjukkan pada Tabel 2 dan Tabel 3.

Tabel 2.

Hasil analisis XRD ekstrak tanin gambir

\begin{tabular}{lllll}
\hline $\begin{array}{l}\text { Position } \\
{\left[{ }^{\circ} 2 \theta\right]}\end{array}$ & $\begin{array}{l}d \text {-spacing } \\
{[\AA]}\end{array}$ & $\begin{array}{l}\text { Height } \\
{[\text { cts] }}\end{array}$ & $\begin{array}{l}\text { FWHM Left } \\
{\left[{ }^{\circ} 2 \theta\right]}\end{array}$ & $\begin{array}{l}D \\
{[\AA]}\end{array}$ \\
\hline 7,9569 & 11,1116 & 38,46 & 0,3070 & 2,5930 \\
11,4922 & 7,7001 & 37,70 & 0,4093 & 1,9500 \\
13,888 & 6,3767 & 28,74 & 0,3070 & 2,6058 \\
14,7295 & 6,0142 & 47,32 & 0,3070 & 2,6082 \\
16,6804 & 5,3150 & 103,70 & 0,3070 & 2,6144 \\
19,4226 & 4,5703 & 102,89 & 0,3070 & 2,6243 \\
20,9278 & 4,2449 & 118,29 & 0,4093 & 1,9730 \\
23,6521 & 3,7617 & 206,65 & 0,3070 & 2,6428 \\
25,8625 & 3,4451 & 107,74 & 0,6140 & 1,3270 \\
27,6570 & 3,2255 & 91,80 & 0,4093 & 1,9981 \\
29,1334 & 3,0653 & 70,49 & 0,3582 & 2,2906 \\
31,7739 & 2,8163 & 116,35 & 0,3070 & 2,6894 \\
33,1347 & 2,7037 & 24,30 & 0,3070 & 2,6987 \\
34,8740 & 2,5727 & 38,77 & 0,4093 & 2,0336 \\
49,2394 & 1,8506 & 37,09 & 0,3582 & 2,4387 \\
52,4724 & 1,7439 & 17,04 & 0,4093 & 2,1630 \\
55,0434 & 1,6684 & 14,84 & 0,5117 & 1,7500 \\
\hline
\end{tabular}


Tabel 3.

Hasil analisis XRD GTG

\begin{tabular}{lllll}
\hline $\begin{array}{l}\text { Position } \\
{\left[{ }^{\circ} 2 \theta\right]}\end{array}$ & $\begin{array}{l}\text { d-spacing } \\
{[\AA]}\end{array}$ & $\begin{array}{l}\text { Height } \\
{[\mathrm{cts}]}\end{array}$ & $\begin{array}{l}\text { FWHM Left } \\
{\left[{ }^{\circ} 2 \theta\right]}\end{array}$ & $\begin{array}{l}D \\
{[\AA]}\end{array}$ \\
\hline 14,6724 & 6,0375 & 32,03 & 0,3070 & 2,6081 \\
20,6985 & 4,2914 & 34,71 & 0,4093 & 1,9723 \\
25,7302 & 3,4625 & 50,43 & 0,5117 & 1,5919 \\
26,5621 & 3,3559 & 154,24 & 0,3070 & 2,6578 \\
28,9446 & 3,0848 & 54,67 & 0,4093 & 2,0038 \\
31,8009 & 2,8140 & 111,97 & 0,5117 & 1,6137 \\
32,9773 & 2,7162 & 45,65 & 0,3070 & 2,6976 \\
34,0696 & 2,6316 & 31,88 & 0,3070 & 2,7054 \\
39,3997 & 2,2870 & 16,74 & 0,3070 & 2,7475 \\
46,8920 & 1,9376 & 21,16 & 0,3070 & 2,8195 \\
49,5630 & 1,8393 & 18,6 & 0,8187 & 1,0684 \\
53,1031 & 1,7247 & 21,09 & 0,4093 & 2,1689 \\
\hline
\end{tabular}

Dari hasil analisis XRD ekstrak tanin gambir pada Tabel 2 dapat dilihat bahwa puncak tertinggi berada pada posisi $2 \theta=20,92^{\circ}, 23,62^{\circ}$ dan $31,77^{\circ}$ dan dikonfirmasi sebagai senyawa tanin (Makeswari and Santhi, 2013). Sedangkan dari hasil analisis untuk GTG pada Tabel 3, puncak tertinggi pada posisi $2 \theta=26,56^{\circ}$ dan $31,08^{\circ}$ merujuk pada kelompok senyawa tanin berdasarkan data The International Centre for Diffraction Data (ICDD®) dengan nomor referensi 00-043-1949 dan 00-038-1922.

Dengan mengukur nilai FWHM dari sejumlah puncak utama dan memasukkan ke dalam persamaan Scherrer maka dapat diketahui ukuran kristal dari ekstrak tanin yaitu 1,33-2,70 ̊. Adapun ukuran kristal GTG yaitu 1,07-2,82 ̊. Bila dibandingkan antara ukuran kristal sebelum dan sesudah reaksi polimerisasi, ukuran kristal tidak terlalu banyak berubah dengan ukuran maksimal kristal naik dari 2,70 ̊ menjadi 2,82 ̊. Hal ini dikarenakan perubahan struktur terjadi pada skala molekul sehingga tidak berdampak secara siginifikan pada ukuran kristalnya.

Pola difraksi sinar $\mathrm{X}$ dari ekstrak tanin gambir dan GTG dapat dilihat pada Gambar 3. Pola difraksi ekstrak tanin memiliki puncak yang cukup lebar yang menandakan bahwa tingkat kristalinitas masih rendah dimana struktur amorf masih mendominasi. Dari spektrum XRD untuk ekstrak tanin tampak puncakpuncak kecil yang menunjukkan adanya pengotor dalam tanin. Adapun pola difraksi biosorben yang dihasilkan menunjukkan puncak lebar yang menandakan bahwa tingkat kristalinitas dari biosorben berbasis tanin masih rendah.

\subsection{Kapasitas adsorpsi ion logam $\mathbf{P b}^{2+}$}

Hasil analisis ion $\mathrm{Pb}^{2+}$ yang teradsorpsi pada berbagai konsentrasi dapat dilihat pada Tabel 4. Dari persamaan garis linear yang didapat melalui pembuatan grafik isoterm Freundlich pada Gambar 3(a) dan grafik isoterm Langmuir pada Gambar 3(b), dapat ditentukan parameter Freundlich $\left(\mathrm{K}_{\mathrm{F}}\right.$ dan $\left.\mathrm{n}\right)$ dan parameter Langmuir ( $\mathrm{K}_{\mathrm{L}}$ dan $\left.\mathrm{Qo}\right)$ adsorpsi biosorben terhadap ion logam $\mathrm{Pb}^{2+}$ sesuai dengan persamaan Freundlich.

Tabel 4 menunjukan bahwa semakin besar konsentrasi ion $\mathrm{Pb}^{2+}$ maka semakin banyak ion $\mathrm{Pb}^{2+}$ yang terserap, hal ini dapat dilihat terjadi peningkatan daya serap yang diperoleh dari konsentrasi 5 ppm sampai $30 \mathrm{ppm}$. Hasil ini sesuai seperti adsorpsi ion logam $\mathrm{Pb}^{2+}$ yang dilaporkan oleh (Deviyanti et al., 2014). Hasil pengukuran tersebut dimasukkan ke dalam grafik persamaan Freundlich dan persamaan Langmuir untuk menentukan pola isoterm yang sesuai dengan besarnya kapasitas adsorpsi, sebagaimana dapat dilihat pada Gambar 4 (a) dan (b).

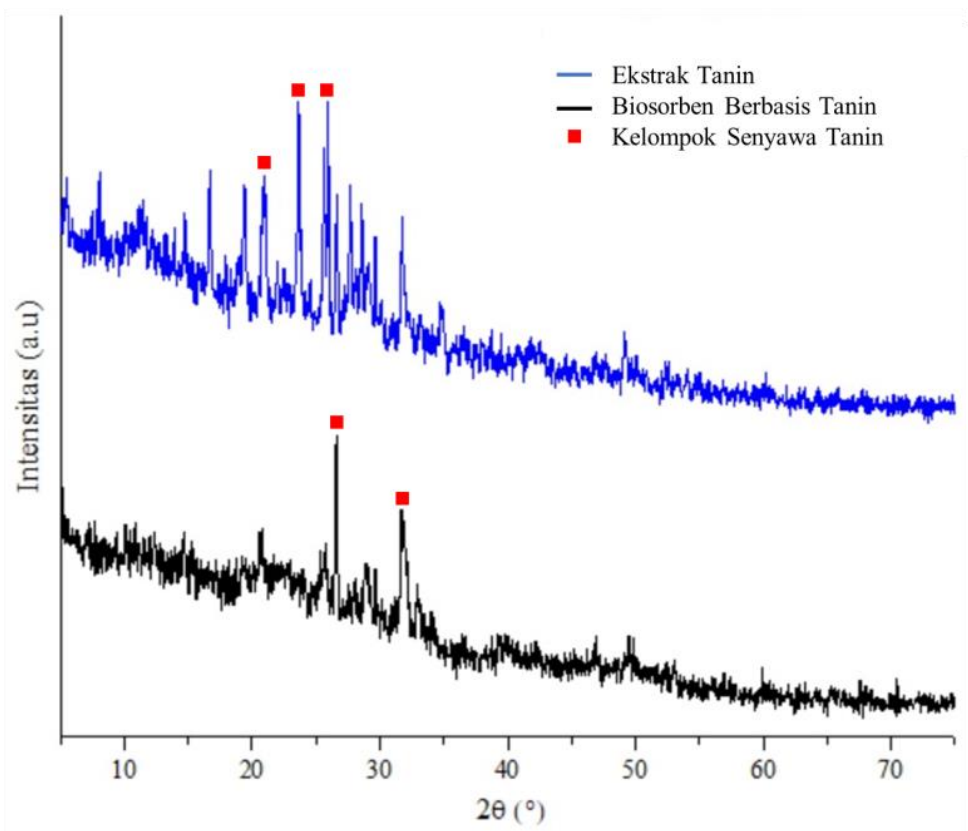

Gambar 3. Pola difraksi sinar X dari ekstrak tanin gambir dan biosorben berbasis tanin gambir

Dari kurva isoterm adsorpsi Freundlich yang diperoleh dapat dilihat bahwa hasil analisis regresi linier $\left(\mathrm{R}^{2}\right)$ menunjukan nilai 0,8525 dengan persamaan garis $y$
$=1,808 x-1,65$. Berdasarkan persamaan linier isoterm Freundlich (persamaan 3), kemampuan relatif dari suatu adsorben dalam mengadsorpsi adsorbat dinyatakan 
sebagai konstanta Freundlich $\left(\mathrm{K}_{\mathrm{F}}\right)$. Semakin besar nilai $\mathrm{K}_{\mathrm{F}}$ maka semakin besar kemampuan suatu adsorben dalam mengadsorpsi. Adapun kekuatan interaksi antara adsorben dan adsorbat dapat dilihat dari nilai $1 / n$, semakin kecil nilai $1 / \mathrm{n}$ maka semakin kuat interaksi antara adsorben dengan adsorbat (Deviyanti et al., 2014). Nilai $\mathrm{K}_{\mathrm{F}}$ dan $1 / \mathrm{n}$ yang diperoleh dari GTG masingmasing sebesar 44,6683 mg/g dan 1,808. Nilai ini lebih rendah dibandingkan dengan kemampuan adsorbsi dari QTG yaitu sebesar 483 mg/g (Sánchez-Martín et al., 2010) namun sudah cukup baik sebagai adsorben.

Pada kurva isoterm Langmuir dapat dilihat nilai dari analisis regresi linier $\left(\mathrm{R}^{2}\right)$ adalah 0,4179 dengan persamaan dari $y=-2,0338 x+24,537$. Dari hasil perhitungan maka dapat diketahui kapasitas adsorpsi maksimum GTG terhadap ion logam $\mathrm{Pb}^{2+}$ adalah sebesar 0,4917 mg/g dan nilai konstanta kesetimbangan adsorpsi sebesar 0,0408 L/mg.

Berdasarkan nilai $\mathrm{R}^{2}$, model adsorpsi ion $\mathrm{Pb}^{2+}$ oleh biosorben berbasis tanin lebih sesuai dengan isoterm Freundlich dibandingkan dengan isoterm Langmuir. Adsorpsi ion $\mathrm{Pb}^{2+}$ oleh bisorben berbasis tanin yang sesuai dengan pola isoterm adsorpsi Freundlich mengindikasi bahwa adsorpsi di permukaan adsorben terjadi pada situs-situs aktif yang bersifat heterogen (Jasmal et al., 2015).

Tabel 4.

Rata-rata ion $\mathrm{Pb}^{2+}$ yang teradsorpsi dengan menggunakan biosorben berbasis tanin gambir pada berbagai konsentrasi dengan waktu kontak 3 jam

\begin{tabular}{lllllllll}
$\begin{array}{l}\text { GTG } \\
(\text { gram })\end{array}$ & $\begin{array}{l}\text { Konsentrasi } \\
\text { Awal }\left(\mathrm{C}_{0}\right) \\
(\mathrm{ppm})\end{array}$ & $\begin{array}{l}\text { Konsentrasi } \\
\text { Akhir }\left(\mathrm{C}_{\mathrm{e}}\right) \\
(\mathrm{ppm})\end{array}$ & $\begin{array}{l}\text { Konsentrasi } \\
\text { terserap } \\
(\mathrm{ppm})\end{array}$ & $\begin{array}{l}\text { Daya serap } \\
(\mathrm{q})(\mathrm{mg} / \mathrm{g})\end{array}$ & Log Ce & Log q & Ce/q & $\begin{array}{l}\text { Log } \\
\text { Ce/q }\end{array}$ \\
\hline 0,5033 & 5 & 2.8250 & 2.1750 & 0.1080 & 0.4510 & -0.9664 & 26.1485 & 1.4174 \\
0,5018 & 10 & 4.4400 & 5.5600 & 0.2770 & 0.6474 & -0.5575 & 16.0287 & 1.2049 \\
0,5029 & 15 & 4.3350 & 10.6650 & 0.5302 & 0.6370 & -0.2756 & 8.1765 & 0.9126 \\
0,5007 & 20 & 5.7950 & 14.2050 & 0.7093 & 0.7631 & -0.1492 & 8.1705 & 0.9122 \\
0,5041 & 25 & 8.4050 & 16.5950 & 0.8230 & 0.9245 & -0.0846 & 10.2126 & 1.0091 \\
0,505 & 30 & 8.7200 & 21.2800 & 1.0535 & 0.9405 & 0.0226 & 8.2774 & 0.9179 \\
\hline
\end{tabular}

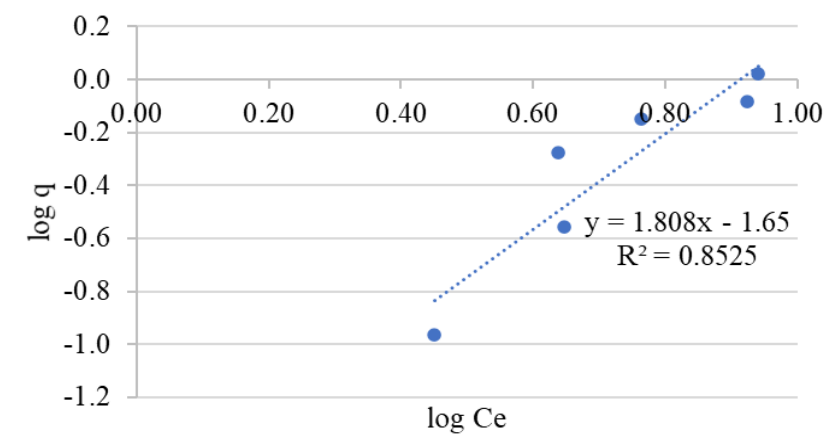

(a)

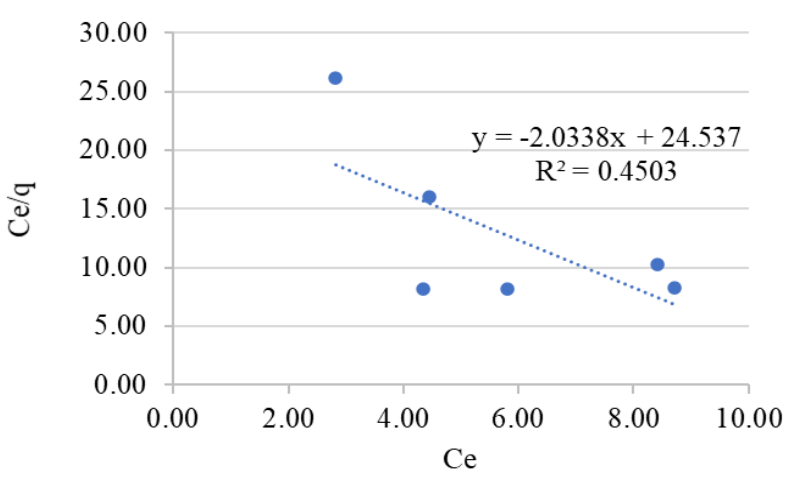

(b)

Gambar 4. (a) Grafik isoterm Freundlich dan (b) grafik isoterm Langmuir adsorpsi ion logam $\mathrm{Pb}^{2+}$ oleh biosorben berbasis tanin gambir

\section{Kesimpulan}

Gel tanin gambir (GTG) dapat disintesis melalui reaksi polimerisasi dengan penambahan formaldehida. GTG yang dihasilkan merupakan polimer senyawa tanin, ditandai dengan adanya jembatan metilen $\left(-\mathrm{CH}_{2}-\right)$ dan jembatan metilen eter $(\mathrm{C}-\mathrm{O}-\mathrm{C})$ pada pembacaan spektrum inframerah. Tingkat kristalinitas GTG masih rendah dengan ukuran kristal 1,07-2,82 $\AA$. Proses adsorpsi ion logam $\mathrm{Pb}^{2+}$ oleh GTG mengikuti persamaan isoterm adsorpsi Freundlich dengan kapasitas adsorpsi maksimum sebesar $0,4917 \mathrm{mg} / \mathrm{g}$.

\section{Ucapan terima kasih}

Terima kasih kepada Laboratorium Proses dan Laboratorium Pengujian Baristand Industri Padang yang telah memberikan fasilitas untuk pelaksanaan penelitian.

\section{Daftar pustaka}

Aisyahlika, S.Z., Firdaus, M.L., Elvia, R., 2018. Kapasitas adsorpsi arang aktif cangkang Bintaro (Cerbera odollam) terhadap zat warna sintetis Reactive RED-120 dan Reactive BLUE-198. J. Pendidik. Dan Ilmu Kim. 2, 148-155.

Alvares Rodrigues, L., Koibuchi Sakane, K., Alves Nunes Simonetti, E., Patrocínio Thim, G., 2015. Cr total removal in aqueous solution by PHENOTAN AP based tannin gel (TFC). J. Environ. Chem. Eng. 3, 725-733. https://doi.org/10.1016/j.jece.2015.04. 006

Anggraini, D., Rahmawati, N., Hafsah, D.S., 2013. Formulasi gel antijerawat dari ekstrak etil asetat gambir. J. Penelit. Farm. Indones. 1, 62-66.

Arbenz, A., Avérous, L., 2015. Oxyalkylation of gambier tannin-Synthesis and characterization of ensuing biobased polyols. Ind. Crops Prod. 67, 295304. https://doi.org/10.1016/j.indcrop.2015.01.073 
Bacelo, H., Vieira, B.R.C., Santos, S.C.R., Boaventura, R.A.R., Botelho, C.M.S., 2018. Recovery and valorization of tannins from a forest waste as an adsorbent for antimony uptake. J. Clean. Prod. 198, 1324-1335. https://doi.org/10.1016/j.jclepro.2018. 07.086

Bacelo, H.A.M., Santos, S.C.R., Botelho, C.M.S., 2016. Tannin-based biosorbents for environmental applications - A review. Chem. Eng. J. 303, 575-587. https://doi.org/10.1016/j.cej.2016.06.044

Beltrán-Heredia, J., Palo, P., Sánchez-Martín, J., Domínguez, J.R., Gonzáez, T., 2012. Natural adsorbents derived from tannin extracts for pharmaceutical removal in water. Ind. Eng. Chem. Res. 51, 50-57. https://doi.org/10.1021/ie201017t

Deviyanti, Sumiati, S., Netti, H., 2014. Kapasitas adsorpsi arang aktif kulit singkong terhadap ion logam timbal ( $\mathrm{Pb} 2+)$. J. Chem. 15, 58-65.

Failisnur, Sofyan, 2016. Pengaruh suhu dan lama pencelupan benang katun pada pewarnaan alami dengan ekstrak gambir (Uncaria gambir Roxb). J. Litbang Ind. 6, 25-37. https://doi.org/10.24960/ jli.v6i1.716.25-37

Fauza, H., 2014. Gambier: Indonesia leading commodities in the past. Int. J. Adv. Sci. Eng. Inf. Technol. 4, 455. https://doi.org/10.18517/ijaseit. 4.6.463

Ferdinal, N., 2014. A Simple purification method of catechin from Gambier. Int. J. Adv. Sci. Eng. Inf. Technol. 4, 441. https://doi.org/10.18517/ijaseit. 4.6.460

Gurung, M., Adhikari, B.B., Kawakita, H., Ohto, K., Inoue, K., Alam, S., 2011. Recovery of $\mathrm{Au}(\mathrm{III})$ by using low cost adsorbent prepared from persimmon tannin extract. Chem. Eng. J. 174, 556-563. https://doi.org/10.1016/j.cej.2011.09.039

Hafiz, N.L.M., Tahir, P.M.D., Hua, L.S., Abidin, Z.Z., Sabaruddin, F.A., Yunus, N.M., Abdullah, U.H., Abdul Khalil, H.P.S., 2020. Curing and thermal properties of co-polymerized tannin phenolformaldehyde resin for bonding wood veneers. J. Mater. Res. Technol. 9, 6994-7001. https://doi.org/10.1016/j.jmrt.2020.05.029

Jasmal, Sulfikar, Ramlawati, 2015. Kapasitas adsorpsi arang aktif ijuk pohon aren (Arenga pinnata) terhadap $\mathrm{Pb} 2+$. J. Sainsmat 4, 57-66.

Makeswari, M., Santhi, T., 2013. Tannin gel derived from leaves of Ricinus Communis as an adsorbent for the removal of $\mathrm{Cu}$ (II) and $\mathrm{Ni}$ (II) ions from aqueous solution. Int. J. Mod. Eng. Res. 3, 32553266.

Masruroh, Manggara, A.B., Papilaka, T., Tjahjanto, R.T., 2013. Penentuan ukuran kristal (crystallite size) lapisan tipis PZT dengan metode XRD melalui pendekatan persamaan Debye Scherrer. Erud. J. Educ. Innov. 1, 24-29. https://doi.org/10.18551/ erudio.1-2.4

Meethale Kunnambath, P., Thirumalaisamy, S., 2015. Characterization and utilization of tannin extract for the selective adsorption of Ni (II) ions from water. J. Chem. 2015, 1-9. https://doi.org/10.1155/2015/ 498359
Morisada, S., Kim, Y.H., Ogata, T., Marutani, Y., Nakano, Y., 2011. Improved adsorption behaviors of amine-modified tannin gel for palladium and platinum ions in acidic chloride solutions. Ind. Eng. Chem. Res. 50, 1875-1880. https://doi.org/10. 1021/ie102193a

Sánchez-Martín, J., Beltrán-Heredia, J., Gibello-Pérez, P., 2011. Adsorbent biopolymers from tannin extracts for water treatment. Chem. Eng. J. 168, 1241-1247. https://doi.org/10.1016/j.cej.2011.02.022

Sánchez-Martín, J., González-Velasco, M., BeltránHeredia, J., Gragera-Carvajal, J., SalgueroFernández, J., 2010. Novel tannin-based adsorbent in removing cationic dye (Methylene Blue) from aqueous solution. Kinetics and equilibrium studies. J. Hazard. Mater. 174, 9-16. https://doi.org/10.1016/ j.jhazmat.2009.09.008

Santiago-Medina, F.J., Tenorio-Alfonso, A., DelgadoSánchez, C., Basso, M.C., Pizzi, A., Celzard, A., Fierro, V., Sánchez, M.C., Franco, J.M., 2018. Projectable tannin foams by mechanical and chemical expansion. Ind. Crops Prod. 120, 90-96. https://doi.org/10.1016/j.indcrop.2018.04.048

Silfia, S., Failisnur, F., Sofyan, S., 2018. Analysis of functional groups, distribution, and particle size of stamp ink from gambier (Uncaria gambir Roxb) with $\mathrm{NaOH}$ and $\mathrm{Al} 2(\mathrm{SO} 4) 3$ complexing compounds. J. Litbang Ind. 8, 31-38.

Sun, X., Zhang, J., You, Y., 2020. Enhancement of $\mathrm{Cu}(\mathrm{II})$ removal by carbon disulfide modified black wattle tannin gel. Colloids Surfaces A Physicochem. Eng. Asp. 608, 125594. https://doi.org/10.1016/ j.colsurfa.2020.125594

Wang, Y., Wang, F., Wan, T., Cheng, S., Xu, G., Cao, R., Gao, M., 2013. Enhanced adsorption of $\mathrm{Pb}(\mathrm{II})$ ions from aqueous solution by persimmon tanninactivated carbon composites. J. Wuhan Univ. Technol. Mater. Sci. Ed. 28, 650-657. https://doi.org/10.1007/s11595-013-0746-X

Xu, Q., Wang, Yulu, Jin, L., Wang, Yu, Qin, M., 2017. Adsorption of $\mathrm{Cu}$ (II), $\mathrm{Pb}$ (II) and $\mathrm{Cr}$ (VI) from aqueous solutions using black wattle tanninimmobilized nanocellulose. J. Hazard. Mater. 339, 91-99. https://doi.org/10.1016/j.jhazmat.2017.06.005

Yeni, G., Syafruddin, D., Kasim, A., Amos, 2016. Pengujian kemampuan daya samak cube black dan limbah cair gambir terhadap mutu kulit tersamak. J. Litbang Ind. 6, 73-82.

Yeni, G., Syamsu, K., Mardliyati, E., dan Hendri Muchtar, 2017. Penentuan teknologi proses pembuatan gambir murni dan katekin terstandar dari gambir asalan,. J. Litbang Ind. 7, 1-10. https://doi.org/10.24960/jli.v7i1.2846.1-10

Yeni, G., Syamsu, K., Suparno, O., Mardliyati, E., Muchtar, H., 2014. Repeated extraction process of raw gambiers (Uncaria gambier Roxb.) for the catechin production as an antioxidant. Int. J. Appl. Eng. Res. 9, 24565-24578.

Yurtsever, M., Şengil, I.A., 2009. Biosorption of Pb(II) ions by modified quebracho tannin resin. J. Hazard. Mater. 163, 58-64. https://doi.org/10.1016/j.jhazmat. 2008.06.077 